Vol. 14 (2005): 224-235.

\title{
The static welfare effects of the accession to the European Union on the Finnish agricultural markets
}

\author{
Jyrki Niemi \\ MTT Agrifood Research Finland, Economic Research, Luutnantintie 13, FI-00410 Helsinki, Finland, \\ e-mail: jyrki.niemi@mtt.fi
}

\begin{abstract}
Finland's entry into the European Union in 1995 and the application of the Common Agricultural Policy have had major repercussions on Finland's agriculture, which faces the major disadvantages of an unfavourable climate and farm structure. This paper attempts to measure the direct static welfare effects associated with the opening of Finnish agricultural markets for more competition. Using a standard comparative static partial equilibrium analysis in the Marshallian economic surplus framework, the welfare effects are calculated for eight major cereal and livestock commodities produced in Finland for the year 2003. The results suggest that farmers, despite the growth in direct payments, have incurred large annual welfare losses ranging from EUR 570 to EUR 600 million. Consumers, on the other hand, have gained from the accession between EUR 815 and 875 million annually. The taxpayers' have gained - as a result of the decrease in the direct subsidies and export restitutions paid by the national budget - between EUR 470 and EUR 580 million. The net welfare benefit in Finland, in terms agricultural sector only, was a welfare benefit of EUR 500-700 million in 2003.
\end{abstract}

Key words: integration, European Union, Common Agricultural Policy, Finland, welfare analysis

\section{Introduction}

Finland's accession to the European Union (EU) in January 1995, and the application of the Common Agricultural Policy (CAP) changed the operational environment of the Finnish food sector considerably. In the closed economy before joining the EU the Finnish food markets were almost completely regulated. As a result of the EU membership the administrative regulation of the food chain was replaced by increased market orientation, which thus directs the development of both agriculture and the food industry. The single European market guarantees the free movement of goods, so that differences in the prices between the member states may 
for the most part result only from e.g. transportation costs or differences in the quality and consumer habits. The minimum prices of agricultural products guaranteed by the CAP are considerably lower than the producer prices under the farm income acts applied in Finland before the EU membership, and the prices also vary more than before.

There has been considerable concern over the impact of Finland's accession to the EU on the agricultural sector. The entry has also generated discussion and debate about the benefits and costs of the CAP in Finland. While interest has been high, only limited research (Penttilä 1997) documenting the welfare effects of accession appear to exist todate. The purpose of this article is to measure the direct welfare effects associated with Finland's accession into the EU and compliance with the CAP on the Finnish agricultural sector.

The welfare effects concern various groups within a country, e.g. consumers, producers, the government, and the overall national economy with its income and resource allocation effects as well as EU countries as a whole. Some of these welfare effects are static, while others are dynamic. The scope of this analysis is limited because of the difficulty in addressing the complete set of effects on the Finnish economy resulting from entry, and the particular interest in identifying the effects in the Finnish agricultural markets. In addition, the analysis concentrates on the static effects, and the inter-group transfers within a country, and neglect the possible inter-country income transfers.

The article starts by discussing briefly the agricultural policy objectives in Finland and the EU, and evaluating the impacts of the application of the CAP on Finnish agriculture. The next section of the paper outlines the traditional economic argument concerning the static welfare effects of removing trade barriers. This is followed by a detailed quantitative analysis on welfare effects of integration. Static calculations are used to illustrate how adopting EU price levels have affected producer and consumer surpluses. The budgetary transfers between Finland and the EU are also examined in the context of the CAP. Some summary remarks are offered in the final section.

\section{Finnish agriculture within the $\mathrm{EU}$}

According to a very general comparison of agricultural policies in the EU (Fearne 1991) and Finland before the EU membership (Kola 1993), the basic principles and means seemed to be quite similar. The policy was production-oriented in both Finland and the EU. Price and income support as well as border protection in the form of variable levies and import licensing were the primary means. However, differences existed especially with regard to the means by which income objective for the agricultural population was intended to be achieved. Clearly, productivity of agriculture has been stressed more in the EU than Finland. The promotion of structural development, technical progress, and optimum utilisation of production factors have represented the characteristics of productivity development support in the EU, whereas so-called maintenance support of existing structures of both production and regional allocation predominated in Finland (Kola 1993).

The level of agricultural support in Finland was clearly higher than in the EU, as measured by Producer Subsidy Estimate (PSE). While the total percentage PSE in the EU was $47 \%$ in 1994, the respective figure in Finland was $64 \%$. This higher support level was also reflected in higher producer prices in Finland. The desire to become part of the EU led to a change in direction of the Finnish agricultural policy in the early 1990s. However, the producer prices paid in Finland remained much higher than the minimum prices of agricultural products guaranteed by the EU.

At the time of accession, Finnish producer prices were approximately double those in the EU countries. Therefore Finnish farmers faced a change in output prices and direct support which were of exceptional magnitude compared to that of any other country which had ever joined the EU (Table 1). Commitment to the CAP lowered the producer price level in Finland by 40\%, on aggregate, right at the beginning of 1995. Lower feed costs and reduction of other costs compensated only partly for lower prices of agricultural products. 
Niemi, J. Welfare effects associated with opening of Finnish agricultural markets

Table 1. Comparison of market prices and per-unit subsidies received by producers before the EU accession in 1994 and after the entry in $2003(\mathrm{EUR} / \mathrm{kg})$.

\begin{tabular}{|c|c|c|c|c|c|c|}
\hline \multirow[b]{2}{*}{ Commodity } & \multicolumn{3}{|c|}{1994} & \multicolumn{3}{|c|}{2003} \\
\hline & $\begin{array}{c}\text { Market } \\
\text { price }\end{array}$ & $\begin{array}{c}\text { Direct } \\
\text { payment }\end{array}$ & $\begin{array}{c}\text { Per-unit } \\
\text { gross return }\end{array}$ & $\begin{array}{c}\text { Market } \\
\text { price }\end{array}$ & $\begin{array}{c}\text { Direct } \\
\text { payment }\end{array}$ & $\begin{array}{c}\text { Per-unit } \\
\text { gross return }\end{array}$ \\
\hline Wheat & 0.36 & 0.03 & 0.39 & 0.12 & 0.23 & 0.35 \\
\hline Barley & 0.26 & 0.05 & 0.31 & 0.11 & 0.19 & 0.30 \\
\hline Oats & 0.25 & 0.05 & 0.30 & 0.09 & 0.19 & 0.28 \\
\hline Beef & 3.78 & 2.00 & 5.78 & 1.86 & 1.68 & 3.54 \\
\hline Pork & 2.65 & 0.10 & 2.75 & 1.15 & 0.88 & 2.03 \\
\hline Poultry & 2.00 & 0.09 & 2.09 & 1.17 & 0.77 & 1.94 \\
\hline Eggs & 1.88 & 0.14 & 2.02 & 0.80 & 0.98 & 1.78 \\
\hline Milk & 0.35 & 0.22 & 0.57 & 0.34 & 0.19 & 0.53 \\
\hline
\end{tabular}

Source: MTT Economic Research, Helsinki, Finland.

On market prices only, the survival of Finnish agricultural production would have been very difficult (Kola et al. 1992, Kettunen and Niemi 1994). A comprehensive package of compensatory payments was therefore agreed to facilitate the adjustment. There is a provision in the Accession Treaty concerning the conditions of accession for national long-term aids, especially operating north of the 62 nd parallel. To cover any outstanding problems, Finland was granted permission to pay direct national aid, to which certain restrictions are applied (Kettunen and Niemi 1994).

Agricultural support, its nature and amount, has thus played a significant role in securing the preconditions for agriculture in the different production sectors in different parts of Finland. Because of the unfavourable natural conditions, the role of support in the income formation of agriculture is much greater in Finland than in other parts of the EU. In 2004 support payments totalled about EUR 1.8 billion, which represents $45 \%$ of the total output of agriculture. Despite the growth in the support payments, agricultural income has been falling. Calculated in fixed prices, agricultural income was almost 34\% lower in 2004 than in 1994 (Niemi and Ahlstedt 2005).

Membership in the EU has not lead to any significant changes in the volume of Finnish agricultural production, but the structural development has been very rapid. There were 103,000 farms in 1994, but 10 years later in 2004 there were about
70,000 left, and this trend continues. The number of farms has fallen by more than $3 \%$ a year, and those engaged in livestock production even more. For example, the number of farms specialising in milk production has decreased by almost $7 \%$ a year.

Even though the structure of Finnish agriculture has changed quite rapidly, the development of agricultural productivity has been relatively slow. In 2004, the same use of production inputs yielded about $12 \%$ more than in 1992, showing that productivity grew by a little under $1 \%$ a year. The new economic environment has not promoted agricultural productivity development as was expected.

The consumer price of food fell, on average, by $11 \%$ when Finland joined the EU in 1995. The reduction was caused by the $40 \%$ decrease in the producer price level. The average share of the producer price in the retail price was about $40 \%$, roughly speaking, when milk, meat, and cereal products are taken into account. The share of these in the food expenditure was about $70 \%$. Since the producer prices decrease by $40 \%$, the food prices decrease by about $11 \%$ as a result of this. In other words, the absolute marketing margins of processing and trade remained more or less unaltered as a result of the accession.

Between 1995 and 2004, food prices rose by $11 \%$ in nominal terms, while the general consumer price index rose by $13.4 \%$, which means that food prices are still below the level in 1995 in real terms. 
Vol. 14 (2005): 224-235.

Lower retail prices have in turn stimulated growth in consumption. The EU membership also clearly reinforced the position of retail trade in the food chain relative to the domestic raw material production and food industry. The retail sector has been able to take advantage of the competition between the domestic food companies and between the domestic companies and foreign ones.

\section{Evaluation of the effects of integration}

Quantitative analyses of the effects of integration and trade liberalisation are typically performed in either a partial or general equilibrium framework. By their very nature, partial equilibrium (PE) models allow highly detailed studies on the impacts of trade policy changes to be made for specific markets or products. In contrast, general equilibrium (GE) models, or computable general equilibrium (CGE) models, attempt to describe the effects of trade liberalisation on the economy as a whole and the intersectoral linkage in particular (Shoven and Whalley 1984, Hertel 1997).

The GE models are thus very suitable to analyse the overall trade and welfare effects, as they offer a comprehensive assessment of cross- and inter-industry linkages, including upstream and down stream effects. Yet, the challenges of GE methodology include its complexity, data requirements, dissaggregation issues, and model sensitivity to the selection of key parameters. Model usage typically requires very large start-up costs, so that the usage of a GE model often is limited to larger institutions with skilled resources in this area of economics.

In PE analysis, we limit our view to a specific sector of the domestic and international economy, as we hold "all other things constant", at least conceptually. The main emphasis will be on price, production, and trade effects of integration as applied to individual agricultural commodities (Johnson 1973, Bale and Greenshields 1978, Bale and
Lutz 1981). For the analysis of trade policy principles, the PE model has numerous advantages. It is simple to understand and manipulate. For specific trade policy schemes and interventions, PE analysis provides sharp results that highlight important differences among policy regimes. Such models also require less data and fewer assumptions about key variables in the analysis than the GE models. A disadvantage of the PE approach is that it suppresses interactions between commodities that are actually linked together by substitution and competition (Houck 1984).

It has generally been observed that GE welfare gains turn out to be higher than their PE counterparts (Winters 1987, Gylfason 1994, Tokarick 2003), though there are difficulties in performing strict comparisons between PE and GE models. Hertel (1992) however, finds that the market effects of CAP removal on agricultural markets are very similar, regardless of whether one uses a $\mathrm{PE}$ or GE model. Gohin and Moschini (2004) show that both GE and PE models yields comparable welfare effects when analysing the agricultural sector of developed economies (where agriculture constitutes a small fraction of economic activities), and when no other distortions exist in the rest of the economy.

The focus of this article is the identification of the direct welfare effects of Finland's entry into the EU on the Finnish agricultural markets. More specifically, the objective is to compare the welfare in the existing situation in the EU with that derived from a non-entry scenario. The benefit or cost of integration is the extent to which welfare under current situation exceeds welfare under non-entry scenario.

Most empirical attempts at measuring the effects of different trade policy schemes on welfare are based upon the pragmatic Marshallian concept of economic surplus, where the welfare effects of integration are derived in terms of domestic elasticities of supply and demand, frequently with the assumption of a perfectly elastic foreign-offer curve (Varian 1992). Economic surplus measures are used to compute gains and losses accruing to producers and consumers. This method based on welfare economics is well known, for both its use- 
Niemi, J. Welfare effects associated with opening of Finnish agricultural markets

fulness and limitations. Corden (1957), Deaton and Muellbaur (1980), Just et al. (1982) and Gardner (1987) provide useful discussions of the concept of producer and consumer surplus.

Consider graphically the effects of agricultural policy integration on trade and welfare in the partial equilibrium demand-supply framework. The situation is illustrated in Figure 1, where the domestic demand curve for the product in question is $\mathrm{D}$, domestic supply curve is $\mathrm{S}$, and the supply curve of imports is ES. The domestic product is assumed to be a perfect substitute for the import. Assume now that a binding quota has been imposed on imports, so that with the import barrier in place, the internal market price is kept at $p_{l}$, and hence domestic producers obtain higher prices for more output than if no trade distortions are applied. The direct payment, $s_{l}$, further increases perunit returns to producers from $p_{l}$ to $r_{l}$. This brings total consumption to $C_{1}$ at price $p_{1}$, and production to $Q_{1}$ at per-unit return $r_{1}\left(=p_{1}+s_{I}\right)$.

Consider now that import barriers are removed and market prices are allowed to seek a level consistent with the unfettered flow of imports. This lowers the market price received by domestic producers and paid by domestic consumers from $p_{1}$ to $p_{2}$. Yet, the producers are compensated for the decrease in market prices by a direct subsidy, $s_{2}$, so that per-unit returns to producers, including the subsidy, decrease from $r_{1}$ to $r_{2}$ as a result of the accession. These policy changes raise consumption of the product to $C_{2}$, reduce domestic output to $Q_{2}$, and raise imports from $b c$ to $a d$. Thus, there is an increase on imports as indicated by the arrows.

With the ideas of producer and consumer surplus a somewhat closer analysis of the effects associated with the shift from closed markets to open and more competitive markets can be developed. The removal of import barriers raises consumer surplus by the area $p_{1} g d p_{2}$. This is the partial equilibrium economic benefit of this policy-induced change to consumers. Consumer surplus is fundamentally the net value that consumers as a group obtain by being able to purchase as much as they wish at the going market price rather than having to pay the highest price they would be prepared to offer for each additional unit (Houck 1984). The area $g d c$ is part of the real income gained by consumers because of the price decrease from $p_{1}$ to $p_{2}$.

Producers lose the area $r_{1} j h r_{2}$ in producer surplus value because per-unit returns decrease as a result of the accession. Producer surplus is the net value obtained by owners of productive assets fixed in the sector to be analysed (Houck 1984). The area jih is an efficiency gain in production, re-
Fig. 1. Partial equilibrium effects associated with a removing of trade barriers.

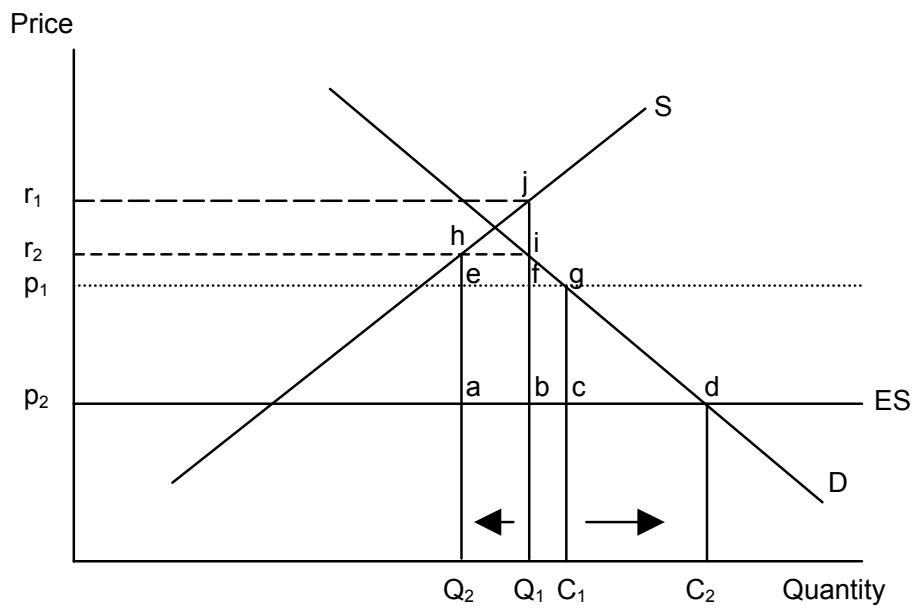


Vol. 14 (2005): 224-235.

flecting the additional marginal value produced elsewhere in the economy because of the decrease in agricultural production. Taxpayers are paying now $r_{2} h a p_{2}$, instead of $r_{l} j f p_{1}$ before the entry.

There are several well-known limitations in the procedure employed above. A static single market analysis ignores the interactions within the food chain and between the food sector and other sectors of the economy, and it does not include the costs of adjustment to trade shocks (e.g. unemployment). Compensating and equivalent variation would be more appropriate techniques than producer and consumer surplus calculation when static effects of integration are analysed. This kind of analysis also ignores factor mobility between countries.

Furthermore, quantification of the welfare effects of the policy change requires knowledge of demand and supply elasticities of agricultural products. This is a limiting aspect because the administered price system distorts supply and demand responses. Technically, the requirement of elasticity estimates does not hinder analysis, if we are satisfied with reasonably accurate qualitative results, despite less precise quantitative estimates. Another limitation is the static nature of the method ignoring adjustment time needed for changes, although knowledge of short-run and long-run elasticity estimates allows for both static and dynamic results. Finally the method implicitly equates individual marginal utility with that of the society.

\section{Quantitative examination of the static welfare effects}

\section{Estimation technique and data}

The quantitative results of this study are derived by using standard partial equilibrium comparative static analysis in the Marshallian economic surplus framework. Economic surplus measures (i.e. producer and consumer surplus) are calculated by comparing the evolution of the agricultural market with and without entry into the EU. Using this method the welfare effects of Finland's entry into the EU and compliance with the CAP are evaluated for eight major cereals and livestock commodities produced and imported in Finland. The range of commodities contained in the analysis spans wheat, barley, oats, beef, pork, poultry, egg and milk. These eight products account for more than 90 percent of the output of Finnish agricultural production at market price.

As with most policy changes, the response of the individuals impacted by integration depends on the time perspective. In this analysis we focus on the medium term, which is defined as the period that at least one factor is fixed. The year of the analysis is year 2003 .

The basic formulae for calculation are represented by equations (1) through (8):

1) estimated domestic production without entry into the EU

$Q_{1}=Q_{2}+n_{s}\left[\left(r_{1}-r_{2}\right) / r_{1}\right] Q_{2}$

2) estimated domestic consumption without entry into the $\mathrm{EU}$

$C_{1}=C_{2}+n_{d}\left[\left(p_{1}-p_{2}\right) / p_{1}\right] C_{2}$

3) net social benefit in production as a result of accession

$\mathrm{NCB}_{\mathrm{p}}=\left[0.5\left(Q_{2}-Q_{1}\right)\right] *\left(r_{2}-r_{1}\right)$

4) net social benefit in consumption as a result of accession

$\mathrm{NCB}_{\mathrm{c}}=\left[0.5\left(C_{2}-C_{1}\right)\right] *\left(p_{1}-p_{2}\right)$

$5)$ welfare gain of producers as a result of accession

$\mathrm{PS}_{\mathrm{d}}=\left[Q_{1}-0.5\left(Q_{2}-Q_{1}\right)\right] *\left(r_{2}-r_{1}\right)$

6) welfare gain of consumers as a result of accession

$$
\mathrm{CS}_{\mathrm{d}}=\left[C_{1}+0.5\left(C_{2}-C_{1}\right)\right] *\left(p_{1}-p_{2}\right)
$$

7) change in taxpayers' expenditure as a result of accession

$\begin{aligned} \mathrm{TX}_{\mathrm{d}}= & \underset{\mathrm{TX}_{2}}{Q_{2}}\left(r_{1}-p_{1}\right)-Q_{2}\left(r_{2}-p_{2}\right)+\mathrm{EX}_{1}+\mathrm{S}_{2}- \\ & -\end{aligned}$

8) net social benefit in society as a result of accession

$\mathrm{NSB}_{\mathrm{d}}=\mathrm{NCB}_{\mathrm{p}}+\mathrm{NCB}_{\mathrm{c}}+\mathrm{TX}_{\mathrm{d}}$

where $r_{l}$ is the per-unit return faced by domestic producers under a non-entry scenario; $r_{2}$ is the per-unit return in the entry scenario in 2003; $p_{1}$ is 
the market price faced by domestic consumers under a non-entry scenario; $p_{2}$ is the market price in 2003; $Q_{1}$ is the simulated production quantity under a non-entry scenario, $Q_{2}$ is the actual quantity of production in 2003; $C_{1}$ is the simulated consumption under a non-entry scenario, $C_{2}$ is the actual quantity of consumption in 2003, $n_{s}$ is ownprice elasticity of supply, $n_{d}$ is own-price elasticity of demand, $\mathrm{EX}_{1}$ represents country's export subsidy payment before the EU membership in 1994, $S_{2}$ represents the sum of direct subsidies received from the European Agricultural Guidance and Guarantee Fund (EAGG) in 2003, and $T X_{2}$ represents country's payment to the EAGG in 2003.

The base year of the analysis is calendar year 2003. The quantity figures, production and consumption levels in year 2003 are based on the statistics compiled by the Information Centre of the Ministry of Agriculture and Forestry. The price figures, per-unit returns faced by domestic producers and market prices faced by domestic consumers, used in this study, are weighted averages calculated at the MTT Economic Research (Table 1). The producers' unit-returns include both sales income and all the support payments allocated to the commodity in question.

Substituting non-entry per-unit returns and prices into the supply and demand equations allows us to estimate a level of consumption and production in the no-entry alternative for 2003. From this, the net social losses and changes in consumer and producer surpluses can be calculated. Information required for the analysis are entry and non-entry prices and direct support payments as well as production and consumption of agricultural products in 2003 and own-price supply and demand elasticity estimates by commodity for Finland.

Market prices and direct aids in nominal terms of 1994 are used as non-entry figures in 2003. Whether the producer price level of 1994 could have been kept by not entering the EU is of course debatable, as the outcome of the Uruguay Round Agreement on Agriculture would have hit the country anyway. One alternative to the prices of 1994 could be to use the price development in Norway as a reference scenario, since Norway was the fourth country negotiating parallel to Finland, Austria and Sweden. One could e.g. start in national prices 1994 and assume that they would have developed parallel two what has happened in Norway since 1994. However, that would lead to very high price increases, which is doubtful in the Finnish case. In the same way, using real prices of 1994 as non-entry prices in 2003 would lead to much larger price differences than using nominal prices of 1994.

Demand is estimated here at the wholesale level, and not at the final consumption level. Surplus measured along the wholesale demands equals the final demand surplus under two conditions: when marketing inputs and farm products are combined in fixed proportions, and when inputs are available at given prices, i.e. there exist no rents (Just et al. 1982, Gardner 1987).

\section{Supply and demand elasticities}

The price elasticities of demand and supply play an important role in the calculation of the welfare effects. By using the price elasticities of demand and supply, the effects of the price changes, resulting from the EU accession, on the consumption and production are calculated. The own-price elasticities of supply and demand, used in this study, are presented in Table 2. Supply elasticities are based on studies by Kola (1991), Penttilä (1997), Niemi (2003) and Hyytiäinen (2005). Demand elasticities were taken from Rouhiainen (1979) and Laurila (1994). In all cases these elasticities are long-run equilibrium elasticities based on time series econometric estimates. The elasticities are generally estimated as single equations using ordinary least squares (OLS).

There are significant problems with most of these elasticity estimates. First of all, there is the difficulty of determining what the ceteris paribus effect of a price change of the product itself, and what is caused by the price change of a related product, income changes or price shift. Furthermore, the results of the elasticity calculations often differ a great deal. Different studies attempt to define elasticities in different situations. Some stud- 
Vol. 14 (2005): 224-235.

Table 2. Own price elasticities of demand and supply of agricultural products in Finland.

\begin{tabular}{lccccc}
\hline & \multicolumn{2}{c}{ Demand elasticities } & & \multicolumn{2}{c}{ Supply elasticities } \\
\cline { 2 - 3 } \cline { 5 - 6 } Commodity & Low & High & & Low & High \\
\hline Wheat & -0.15 & -0.35 & & 0.25 & 0.70 \\
Barley & -0.10 & -0.30 & & 0.10 & 0.50 \\
Oats & -0.10 & -0.30 & & 0.10 & 0.45 \\
Beef & -0.10 & -0.35 & & 0.05 & 0.45 \\
Pork & -0.15 & -0.45 & & 0.00 & 0.30 \\
Poultry & -0.10 & -0.40 & & 0.20 & 0.80 \\
Eggs & -0.10 & -0.25 & & 0.15 & 0.40 \\
Milk & -0.05 & -0.40 & & 0.10 & 0.75 \\
\hline
\end{tabular}

Sources: Rouhiainen (1979), Kola (1991), Laurila (1994), Penttilä (1997), Niemi (2003), and Hyytiäinen (2005).

ies calculate only product specific elasticities and ignore the cross-price effects.

Most empirical work on the supply elasticities draw upon the general specification of supply relations as follows:

$$
Q_{t}=\alpha_{0}+\beta P_{t}+\gamma_{j} X_{j t}+u_{i t}
$$

where $Q$ is some output measurement, $P$ is some price variable, $X$ is a set of other explanatory variables, $t$ is the time period index, $j$ is a variable index, and $u_{i t}$ is the usual error term. On the price side, most researches assume that farmers anticipate prices from their knowledge of current and past price.

A major source of differences among the supply studies has to do with properly controlling for non-price factors affecting production such as weather, infrastructure and technological changes which prices. Studies vary in this regard depending on the availability of data and on the authors' judgments as to the relevance of particular non-price variables.

On the demand side, the general specification posits that demand is a function of price and income. Rouhiainen (1979) employed single equation methodology to estimate demand elasticities by using disappearance data at the national level, often referred as the Food Balance Sheets. Laurila (1994) employed the Almost Ideal Demand Sys- tem (AIDS) to analyse the demand for food products in Finland in a system context.

It is important to note that in this study the cross-price terms are suppressed, and the accession effects on production and consumption are explained solely by own-price effects. As supply and demand functions are homogeneous of degree zero in prices, it is not theoretically consistent to simply suppress cross-price elasticities (even though the cross-price terms are usually small).

In particular, the impacts of the application of CAP on production costs in the livestock sectors have been ignored in the analysis. The fact that decreases in gain prices resulted in decreased prices for animal feed is not taken into account.

Because of these methodological drawbacks, and because elasticity estimates differ widely from researcher to researcher, a range analysis is used in the study. In range analysis different own-price elasticities are used to estimate the accession effects on production and consumption. The purpose of using different own-price elasticities is to demonstrate the "sensitivity" of the results to changes in the elasticity estimates. Thus, the results of the study provide orders of magnitude rather than exact measures.

Regarding the performance of the elasticities used in this study, the actual development in production as well consumption lends support to the lower bound elasticities. By using the high elasticities, the estimated impact of accession on the volume of agricultural production, in particular, is much larger than what has actually taken place between 1994 and 2003.

\section{Results}

\section{Effects on production and trade}

The effects of entry into the EU on production and consumption volumes are summarised in Table 3 , from which a number of points can be made. Since accession has decreased per-unit returns received by agricultural producers, it has also decreased the 
Niemi, J. Welfare effects associated with opening of Finnish agricultural markets

Table 3. Estimated percentage changes in agricultural production and consumption in Finland as a result of the EU accession.

\begin{tabular}{lrrrrr}
\hline & \multicolumn{2}{c}{$\begin{array}{c}\text { Estimated change } \\
\text { in production }\end{array}$} & & \multicolumn{2}{c}{$\begin{array}{c}\text { Estimated change } \\
\text { in consumption }\end{array}$} \\
\cline { 2 - 3 } \cline { 5 - 6 } Commodity & Low & High & & Low & High \\
\hline Wheat & -2.4 & -6.4 & & 10.8 & 29.3 \\
Barley & -0.5 & -2.4 & & 6.4 & 21.9 \\
Oats & -0.6 & -2.8 & & 6.7 & 23.3 \\
Beef & -1.9 & -14.9 & & 5.4 & 21.7 \\
Pork & 0.0 & -7.3 & & 9.3 & 34.1 \\
Poultry & -1.4 & -5.5 & & 4.3 & 19.9 \\
Eggs & -1.8 & -4.5 & & 6.1 & 16.8 \\
Milk & -0.9 & -6.1 & & 0.2 & 1.7 \\
\hline
\end{tabular}

volume of production, when production and supply are positively related to producers' returns. On the other hand, as a result of lower market prices there is a considerable increase in domestic consumption with the entry into the EU. The effects on trade are merely a combination of the effects on production and consumption, since stocks are assumed to be constant. The entry has caused an increment in the import of all agricultural products analysed.

\section{Effects on economic welfare}

The net social benefits in consumption and production of agricultural commodities as a result of integration are displayed in Table 4. One can view these benefits as (1) the real income gain by consumers, and (2) the efficiency gain in production. The consumers gain economic value as internal prices of agricultural products decrease from previous level. The efficiency gain in production reflects part of the additional marginal value produced elsewhere in the economy because of the decrease in domestic agricultural production.

The sum of net social benefits in production and in consumption for the Finnish economy range from EUR 30 million (the low elasticity case) to EUR 120 million (the high elasticity case). Consumption benefits range from a high of EUR 90 million to a low of EUR 30 million. And net benefits in production range between zero and EUR 30 million. In general, the ranking of the total net social benefits corresponds to what we might expect. The pork and beef industries have incurred the highest benefit, both ranging from EUR 6-7 million to EUR 35-38 million.

As the results in Table 5 indicate, the most sizeable effects of entry are the welfare transfers between consumers and producers. Consumers have gained about EUR 815-875 million for the total of eight major commodities analysed. Clearly, these gains are important to consumers, even though the magnitude of these benefits is small relative to market sales. According to the calculation, the pork consumers have incurred the largest gains, about EUR 223-245 million.

Producers, on the other hand, have incurred large welfare losses from a low EUR 570 million

Table 4. Net social benefits of the EU accession in Finnish agriculture, EUR million.

\begin{tabular}{|c|c|c|c|c|c|c|}
\hline \multirow[b]{2}{*}{ Commodity } & \multicolumn{2}{|c|}{$\begin{array}{l}\text { Net social benefit } \\
\text { in production }\end{array}$} & \multicolumn{2}{|c|}{$\begin{array}{l}\text { Net social benefit } \\
\text { in consumption }\end{array}$} & \multicolumn{2}{|c|}{$\begin{array}{l}\text { Sum of net social } \\
\text { benefit in production } \\
\text { and consumption }\end{array}$} \\
\hline & Low & High & Low & High & Low & High \\
\hline Wheat & 0.3 & 0.9 & 5.5 & 12.9 & 5.8 & 13.8 \\
\hline Barley & 0.1 & 0.3 & 3.3 & 9.8 & 3.3 & 10.1 \\
\hline Oats & 0.1 & 0.4 & 2.8 & 8.4 & 2.9 & 8.7 \\
\hline Beef & 2.1 & 18.4 & 4.6 & 16.1 & 6.7 & 34.5 \\
\hline Pork & 0.0 & 5.5 & 10.9 & 32.5 & 10.9 & 38.0 \\
\hline Poultry & 0.1 & 0.4 & 1.4 & 5.7 & 1.5 & 6.1 \\
\hline Eggs & 0.1 & 0.3 & 1.6 & 4.1 & 1.8 & 4.4 \\
\hline Milk & 0.5 & 3.8 & 0 & 0.3 & 0.5 & 4.1 \\
\hline Total & -0.4 & 29.9 & 30.1 & 89.8 & 33.3 & 119.7 \\
\hline
\end{tabular}


Vol. 14 (2005): 224-235.

Table 5. Monetary effects of the EU accession in the Finnish agricultural markets, EUR million.

\begin{tabular}{lrrrrr}
\hline & \multicolumn{2}{c}{$\begin{array}{c}\text { Welfare gain of } \\
\text { producers }\end{array}$} & & \multicolumn{2}{c}{$\begin{array}{c}\text { Welfare gain of } \\
\text { consumers }\end{array}$} \\
\cline { 2 - 3 } \cline { 5 - 6 } Commodity & Low & High & & Low & High \\
\hline Wheat & -26 & -28 & & 107 & 101 \\
Barley & -26 & -26 & & 106 & 99 \\
Oats & -25 & -25 & & 86 & 80 \\
Beef & -217 & -266 & & 176 & 165 \\
Pork & -139 & -155 & & 245 & 223 \\
Poultry & -13 & -14 & & 67 & 63 \\
Eggs & -14 & -15 & & 56 & 53 \\
Milk & -119 & -129 & & 31 & 31 \\
Total & -570 & -600 & & 875 & 815 \\
\hline
\end{tabular}

to a high EUR 600 million. The magnitude of the losses due to the CAP has been most pronounced for the beef and pork producers. Beef producers' welfare loss ranged from EUR 213 to EUR 229 million. Pork producers have lost from EUR 135 to EUR 144 million.

\section{Budgetary transfers}

Apart from transfers between producers and consumers, there are budgetary transfers, which must also be taken into account when documenting welfare changes in the whole society. The calculations show that agricultural budgetary benefit from the application of the CAP in Finland range from EUR 470 million (the low elasticity case) to EUR 580 million (the high elasticity case). In other words, taxpayers have gained between EUR 470 to 580 million from the CAP. The taxpayers' welfare gain is mainly a result of the decline in export subsidy payments. The export support of agricultural products has been abolished from the state budget, because the export cost charges are paid from the EU funds.

In the first years of Finland's membership, the support for the price adjustment of agriculture in the transitional period actually increased the state expenditure, but during the post-entry period the state expenditure has gradually decreased. In addition, it is estimated that Finland's receipts from the European Agricultural Guidance and Guarantee Fund (EAGG) have been higher than Finland's contribution to the fund over the first ten years in the EU.

In 2003 Finland's receipts from the EAGG amounted to EUR 760 million. Finland's exact contribution to the EAGG is not known, since payments are made to the EU budget as a whole and not to each special fund separately. However, if we make the usual assumption that the proportion of a member state's contribution that goes to EAGG is equal to the share of EAGG in the total EU budget, we find that Finland's contribution to the fund in 2003 should be equal to EUR 625 million.

\section{Conclusions}

The main objective of this paper is to evaluate the welfare effects of Finland's accession to the European Union generated by the application of the Common Agricultural Policy. Analysis is focused on static effects and results are derived from a very simple partial equilibrium model that distinguishes eight agricultural commodities but ignores supply and demand interactions between these eight products. While robust not enough to include income and second round resource allocation effects, or dynamic adjustment in the industry, this approach nonetheless provides a useful framework for discussing benefits and costs of the integration into the EU.

The benefit or cost of integration is the extent to which welfare under current situation exceeds welfare derived from a hypothetical non-entry situation. This is what we have attempted to measure. Others (i.e. politicians) will have to evaluate and select what benefits and costs are desirable and acceptable. The quantitative results of the study indicate that Finland has incurred welfare benefits resulting from the application of the CAP. The most sizeable effects of integration are the welfare transfers between consumers and producers. According 
to the study, consumers have gained between EUR 815 and 875 million for the total of eight major commodities analysed. Farmers, on the other hand, have incurred large welfare losses from EUR 570 to EUR 600 million. As a result of the decrease in subsidies paid by the government, the taxpayers' welfare gain range from EUR 470 to EUR 580 million. The taxpayers' welfare gain is mainly a result of the decline in export subsidy payments. According to the study, the net social benefit in Finland of the application of the CAP, in terms agricultural sector only, was a welfare benefit of EUR 500-700 million.

\section{References}

Bale, M. \& Greenshields, B.L. 1978. Japanese agricultural distortions and their welfare value. American Journal of Agricultural Economics 60: 59-64.

Bale, M. \& Lutz, E. 1981. Price distortions in agriculture and their effects: An international comparison. American Journal of Agricultural Economics 63: 8-22.

Corden, W.M. 1957. The calculation of the cost of protection. Economic Record 33: 29-51.

Deaton, A. \& Muellbauer, J. 1980. Economics of consumer behaviour. New York: Cambridge University Press. $450 \mathrm{p}$.

Fearne, A. 1991. The history and development of the CAP 1945-85. In: Ritson, C. \& Harvey, D. (eds.). The Common Agricultural Policy and the world economy. Waalingford: CAB International. p. 21-70.

Gardner, B. 1987. The economics of agricultural policies. New York: McGraw-Hill. 384 p.

Gohin, A. \& Moschini, C. 2004. Evaluating the market and welfare impacts of agricultural policies in developed countries: Comparison of partial and general equilibrium measures. Paper presented at the International conference on Policy Modelling, EcoMod 2004, 30 June-2 July 2004, Paris. 19 p.

Gylfason, T. 1995. The macroeconomics of European agriculture. Princeton Studies in International Finance 78, International Finance Section. Princeton N. J: Princeton University. $51 \mathrm{p}$.

Hertel, T. 1992. Partial versus general equilibrium analysis of trade policy reform. The Journal of Agricultural Economics Research 44: 3-15.

Hertel, T. (ed.). 1997. Global trade analysis: modelling and applications. Cambridge: Cambridge University Press. $96 \mathrm{p}$.

Houck, J.P. 1984. Elements of agricultural trade policies. New York: MacMillan Publishing Company. 184 p.

Hyytiäinen, P. 2005. Viljan tarjonta Suomessa vuosina
1970-2003. Abstract: Supply of grains in Finland during 1970-2003. Master Thesis, University of Helsinki, Department of Economics and Management. 54 p.

Johnson, D.G. 1973. The impact of freer trade on North American agriculture. American Journal of Agricultural Economics 55: 294-303.

Just, R.E., Hueth, D.L. \& Schmitz, A. 1982. Applied welfare economics and public policy. Eaglewood Cliffs: Prentice-Hill, Inc. 85 p.

Kettunen, L. \& Niemi, J. 1994. The EU settlement of Finnish agriculture and national support. Agricultural Economics Research Institute (MTT), research publications 75a. Helsinki: MTTL. 91 p.

Kola, J. 1991. Production control in Finnish agriculture: Determinants of control policy and quantitative and economic efficiency of dairy restriction. Agricultural Economics Research Institute (MTTL), research publications 64. Helsinki: MTTL. $117 \mathrm{p}$.

Kola, J. 1993. Principles of agricultural policy in Finland in relation to the CAP of the EC. In: Kettunen, L. (ed.). Finnish agriculture and European integration. Agricultural Economics Research Institute, research publications 71. Helsinki: MTTL. p. 21-36.

Kola, J., Marttila, J. \& Niemi, J. 1992. Finnish agriculture in European integration: A firm level approach. Agricultural Science in Finland 1: 5-14.

Laurila, I. 1994. Demand for food products in Finland: A demand system approach. Agricultural Science in Finland 3: $315-420$.

Niemi, J. 2003. Supply elasticity estimates for farm products. MTT Economic Research, Mimeogr. Helsinki. 9 p.

Niemi, J. \& Ahlstedt, J. (eds.). 2005. Finnish agriculture and rural industries 2005 - Ten years in the European Union. MTT Economic Research, publications 104a. Helsinki: MTT. $94 \mathrm{p}$.

Penttilä, A. 1997. Suomen EU-jäsenyyden vaikutukset tuottajien ja kuluttajien hyvinvointiin. Abstract: Effects of the EU membership on the welfare of producers and consumers in Finland. Agricultural Economics Research Institute (MTTL), working papers 9/97. Helsinki: MTTL. $44 \mathrm{p}$.

Rouhiainen, J. 1979. Changes in demand for food items in Finland 1950-77 with consumption forecasts for 1980, 1985 and 1990. Agricultural Economics Research Institute (MTTL), research publications 40. Helsinki: MTTL. 84 p.

Shoven, J. \& Whalley, J. 1984. Applied general-equilibrium models of taxation and international trade. Journal of Economic Literature 12: 1007-1051.

Tokarick, S. 2003. Measuring the impact of distortions in agricultural trade in partial and general equilibrium. $\mathrm{Pa}-$ per presented at the International Conference "Agricultural policy reform and the WTO: Where we are heading?", 23-26 June, Capri, Italy. 47 p.

Tongeren, F. van, Meijl, H. van \& Surry, Y. 2001. Global models applied to agricultural and trade policies: a review and assessment. Agricultural Economics 26: 149-172.

Varian, Hal R. 1992. Microeconomic analysis. New York: W.W. Norton \& Company. 506 p.

Winters, A. 1987. The economic consequences of agricultural support: A survey. OECD Economic Studies 9: 754. 
Vol. 14 (2005): 224-235.

\title{
SELOSTUS
}

\section{Yhteisen maatalouspolitiikan soveltamisen hyvinvointivaikutukset Suomessa}

\author{
Jyrki Niemi \\ MTT (Maa- ja elintarviketalouden tutkimuskeskus)
}

Tämän tutkimuksen tavoitteena oli selvittää, miten EU:n yhteisen maatalouspolitiikan soveltaminen Suomessa on vaikuttanut maataloustuotteiden tuottajien ja kuluttajien hyvinvointiin. Tuottajien ja kuluttajien hyvinvointimuutokset määritettiin estimoitujen tuotanto- ja kulutusmäärien avulla. Hyvinvoinnin mittarina käytettiin Marshallin hyvinvointitalousteorian ylijäämäkäsitteitä, joiden avulla EU-jäsenyyden aikainen hyvinvointimuutos määritettiin rahana.

Tutkimuksen mukaan tuottajat ovat kärsineet noin 570-600 miljoonan euron hyvinvointitappion EU-jäsenyyden seurauksena. Kuluttajat ovat sitä vastoin saaneet yhteensä 815-875 miljoonaa euroa hyvinvointivoittoa maataloustuotteiden hintojen laskun myötä. Yhteiskunnan hyvinvointimuutoksen määrittämiseen tarvittava veronmaksajien hyvinvointimuutos saatiin vertaamalla tarkasteluvuosina maataloudelle maksettuja tukia. Valtion varoista maksettujen tukien lasku on tuottanut veronmaksajille noin 470-580 miljoonaa euroa hyvinvointivoittoa. Veronmaksajien hyvinvointivoitto on seurausta lähinnä vientikustannusmaksujen siirtymisestä EU:n budjetin kautta rahoitettaviksi. Koko yhteiskunnalle on koitunut EU-jäsenyyden seurauksena noin 500-700 miljoonaa euroa hyvinvointivoittoa. 